\title{
DEVELOPING GEOGRAFIC INDICATION FOR HASI GOAT MEAT (AN APPROACH TO LINK RESEARCH WITH RURAL DEVELOPMENT)
}

\author{
Petrit Dobi $^{1}$, Roland Bardhi ${ }^{2}$, Ilir Lloha ${ }^{1}$ \\ ${ }^{1}$ Agricultural University of Tirana. Albania \\ ${ }_{2}^{2}$ Mountain Area Development Agency, Albania \\ petrit@rasp.org.al
}

\begin{abstract}
A b s t r a c t: A geographical indication (GI), is a sign used on goods that have a specific geographical origin and possess qualities, reputation or characteristics that are essentially attributable to that origin (WIPO, 2012). Developing geographic indication requires a large amount of work in several sectors including applied research, product development, marketing and community development. The BIODIV Balkan project in Albania, have taken the initiative to develop three pilot GI products. The main objective was to support local products and agro biodiversity heritage of the local agrarian systems, crossing environmental injunction for biodiversity conservation with social and economic objectives of rural development. In the case of Hasi goat kid meat, several studies have been implemented including molecular genetics research, morphologic characterization of the breed, identification of characteristics of the product, identification of local pasture biodiversity, identification of specifics of production system that affect quality of the product, pastoral system and feeding practices, etc., that have been the foundation for identification of product's characteristics attributed to the territory of origin. Based on the product characteristics, territory specifics and human capacities, it was prepared the Code of Practice, which is a document that comprises description of all specifics and all collective rules, to be respected by all group members who want to use the quality mark. Taking in account the complex work, and especially the research needed to identify product specifics, as well as the need for an institution to take the initiative for building GI, the authors consider that research institutions should take the leading role in this process opening a new very applicable research priority.
\end{abstract}

Key words: geographic indication; rural development; Hasi goat meat; products specifics; code of practice

\section{РАЗВОЈ НА ГЕОГРАФСКИТЕ ОЗНАКИ ЗА КОЗЈОТО МЕСО ОД РЕГИОНОТ НАSI (ПРИСТАП ПОВРЗАН СО ИСТРАЖУВАЊЕ НА РУРАЛНИОТ РАЗВОЈ)}

А п с т р а к т: Географската ознака (GI) е знак кој се користи за стоки кои имаат специфично географско потекло и поседуваат квалитет, репутација или карактеристики кои во суштина му се припишуваат на нивното потекло. (WIPO, 2012). Развојот на географските ознаки бара голема работа во неколку сектори, вклучувајќи ги применетите истражувања, развојот на производите, маркетингот и развојот на заедниците. Проектот BIODIV Balkan во Албанија презеде иницијатива за развој на три GI производи. Главната цел беше да ги поддржи локалните производи и земјоделското наследство на биодиверзитетот со социјалните и економските цели на руралниот развој. Во случајот на јарешко месо од регионот Hasi се спроведени неколку студии, вклучувајќ ги истражувањата од молекуларната генетика, морфолошките карактеристики на расата, идентификацијата на карактеристиките на производот, идентификацијата на биодиверзитетот на локалните пасишта, идентификацијата на специфичностите на производниот систем кој влијае на квалитетот на производите, одгледувачкиот систем и исхраната во пракса итн., кои се основа на особините кои можат да му се припишат на географското потекло. Врз основа на карактеристиките на производите, територијалните специфичности и човечкиот капацитет, беше подготвен т.н. Кодекс на праксата, документ кој содржи опис на сите специфичности и сите колективни правила, кои треба да ги почитуваат сите членови на групата кои сакаат да ја користат ознаката за квалитет. Имајќ и ја предвид сложеноста на работата, а особено на истражувањето за да се идентификуваат специфичностите на производот, како и потребата од институционална поддршка во изградба на GI, авторите сметаат дека истражувачките институции треба да преземат водечка улога во отворањето на тој процес, отворајќи нов многу применлив истражувачки приоритет.

Клучни зборови: географски ознаки; рурален развој; козјо месо од Hasi; специфичности на производот; кодекс на праксата 


\section{INTRODUCTION}

A geographical indication (GI) is a sign used on goods that have a specific geographical origin and possess qualities, reputation or characteristics that are essentially attributable to that origin.

The identity of GI products reflects the unique combination of local natural resources (climate, soil, local animal breeds and plant species, tradetional equipment etc.) and cultural assets (traditions, know-how and skills, often handed down from generation to generation) in a given territory, thus establishing specific links among the product, local stakeholders and the territory.

During the period 2012-2016 several studies have been made on Hasi goat breed and its products, aiming to identify, characteristics of Hasi goat kid meat, which is a known product with very good reputation for its taste, and for the characteristic production and management system.

The possibility of building the origin-linked quality products depends on the presence of three main pre-requisites:

- the product: specific quality and reputation;

- the place and the local resources;

- the people: the collective dimension and potential for action.

Each of these elements needs complete and detailed applied research efforts to identify specificities of the product, in order to activate GI building cycle.

\section{MATERIAL AND METHODS}

The essential part of this work is the combination of several studies in different sectors as biodiversity, animal genetics, product composition, identification of elements of production system, economics and sociology, almost all completed by academic staff of Agricultural Yniversity of Tirana and CIHEAM/IAMZ Montpelier.

In order to identify all elements of the GI building process we have used previous researches as well as studies and researches completed during this project.

\section{Data collection}

Two different methods have been used: extensive literature review as well as field research (semi- directive interviews, survey, and direct field observation) on which inductive method has been applied.

For the bibliographic research phase there were used: scientific publications as well as the grey literature which represents all other documentation and publications except scientific ones.

\section{Collective field work and interviews}

The collective fieldwork was organized based on the ECRIS method-guidelines for investigation in social situations. A socio-anthropological approach of the field consisting in comprehensive and semi-directive interviews. Interviews were made all around the Hasi region (Albania) in order to have the largest panel of interviews as possible (Claire Bernard 2014).

Interviews and survey were made with the population of villages, Cahan, Mujaj Kishaj, Domaj, Pus I Thate, Gjinaj, Vlahen, Golaj and Vranisht, in the region. A survey grid was prepared in order to have the same questions for each people interviewed. The questionnaire has 51 questions, 9 of them have multiple answer options with check boxes and two were open ones with descriptive answers (Petrit Dobi, 2016; Alice Garnier, 2014).

Delimitation of the territory is initially based on its geographic and morphological structure, as well as on traditional links and connections of the local communities. Anyway the final delimitation belongs to producers group to be defined as far as inclusion or exclusion of some areas or producers strongly links with criteria in the Code of Practice $(\mathrm{CoP})$.

\section{Scientific research}

Specifics of the goat breed are based on DNA analysis for the genotype using microsatellites, SNP and mtDNA, and on morphological measurements of goats according to Food and Agriculture Organization (FAO) criteria for local breeds and populations (FAO, 2012). For product composition have been used standard methods for evaluation of fat and protein content (respectively Soxhlet extraction and Kjeldahl digestion).

Traditional management and pastoral practices and breeding system have been described based on interviews and partly opened questionnaires 
made on 24 farmers having more the 100 goats per farm. The selection of these farms' size is based on the fact that such farms are more market oriented. Those farms have together, more than $50 \%$ of goat population in Hasi region. Before each interview, a free open discussion was made in order to get confidence of farmers and avoid non-realistic information especially on farm production (Dobi, 2016).

\section{RESULTS AND DISCUSSION}

The possibility of activating the origin-linked quality virtuous circle depends on the presence of three main pre-requisites:

- The product: it presents some specific characteristics linked to geographical origin that gives it a special quality and reputation in the market, resulting in specific consumer demand.

- The place: the special quality characteristics are the result of the natural and human resources of the local area in which it is produced.

- The people: the local producers, having inherited traditions and know-how, together with other local stakeholders, must be motivated to engage in a value creation and preservation process.

\section{The product specific quality and reputation}

The reputation of a product is the first element identified before starting a GI building process. Hasi goat kid meat is one of most known products for its quality, taste, and method of production. Anyway, for registering a GI, reputation is just the beginning of the process which should be followed by definition of product's characteristics. One of characteristics considered important for customers is meat composition. Analyses of the flesh in the biceps femuris $\mathrm{m}$. have shown an average of $3.1 \%$ of fat and $19 \%$ of protein content (Lloha, 2016). This result shows a comparative advantage in the market and it is widely used in promotion of the product in markets which are sensitive towards fat and protein contents.

\section{The place and the local resources}

The special quality characteristics of the meat are the result of the natural and human resources of the local area in which it is produced. The quality of the meat of Hasi goat kids is defined by natural resources, which are the goat breed with its characteristics as well as the environment where the animals are fed and grown.

Hasi goat is recognized as an endemic breed (Dobi et al., 2006). Based on the results of this study and results of previous studies on AFLP (Hoda et al., 2014) and microsatellite markers (Hyka et al., 2013) it was defined genetic distance from other local breeds. On the other side, Hasi goat has a distinct morphological traits which are main identification trait and selection criteria. Animals are ... "Adapted to harsh environment and extensive management. Strong and rustic even during winter season. Welldeveloped body, long legs, well developed udder. Reddish, long hair. Pending ears of middle size, backward curled horns " (Dobi et al.,. "Catalogue of local breeds...", 2006).

The phenotypic differentiation is based on traditional selection criteria applied by farmers. Even nowadays they continue to select goat kids for replacement based on: "Reddish color, medium size pending ears, and backward curled horns, high milk productive mothers with good developed teats, as well as the ability to browse high branches" (Dobi et al., 2016). Morphological uniformity of Hasi goat breed in this territory is an important element of differentiation, and this trait is a criteria introduced in the $\mathrm{CoP}$ in the GI building process.

Hasi area is composed by two types of pastures: mountain pastures mainly used during the summer for grazing as well as for producing hay for winter period, and carstic plain. Carstic plain is composed by large number of sinkholes naturally created in the limestone composition of the terrain. The variety of terrain inside and around sinkholes, depth of the soil, humidity and soil composition, provides conditions for growing to a variety of plants and shrubs of different species. Feeding strategy in the Hasi area, is mainly based on natural forage resources such as low oak forests, scrublands and pastures. Goats are pastured even during winter time unless snow arrives up to their knees and doesn't allow them to move. In such situations, animals are kept indoors and fed with dried oak leafs collected during summer and autumn, hay harvested in rich pastures as well as small quantities of cereals produced in the farms or purchased in the market.

All these plants are used as food for goats as well as other farm animals. Each this variety, and especially the presence of some spicy herbs as Saturea montana, Timus vulgaris, etc., gives to the meat e special taste, and is the base of its reputation. 


\section{The people: the collective dimension and potential for action}

The people: the local producers, having inherited traditions and know-how, together with other local stakeholders, must be motivated to engage in a value creation and preservation process.

The production system in Hasi area is very extensive and is widely applying traditional knowhow. Such management practices are very important for the local population because they make use of rich and valuable local resources, and provide low cost products becoming a major source of income for the residents of the area.

Traditional practices, such as grazing, rational and cyclical utilization of grazing resources depending on season, daylight hours, or category of animals, feeding goat kids with fresh leafs since the second month, use of only locally produced hay and dried leafs, traditional breeding methods, traditional methods of medical treatments etc., are an important cultural asset whose preservation is related to the survival of farms that breed goats in this area.

GI products are a collective brand that belongs to all local actors, and plays an important role in preserving this tradition. The establishment of GI is a process that is predominantly determined by collective action. Strengthening the ties among local stakeholders, places and agricultural and food products is a major step towards sustainable rural development. The managing body for Hasi goat kid meat GI was composed by mainly farmers, milk processors and practical vets. To this group belongs the task to draft and approve the Code of Practice $(\mathrm{CoP})$, which is the document that describes characteristics of the product, methodology of production, and delimitation of the territory where the certified product may originate. In the $\mathrm{CoP}$ are embodied the results of studies and research made in identification phase of GI building process. They have got the power to apply for GI, register and protect the quality mark. The GI as a collective action which involves several shareholders and stakeholders has a large impact on local level, as on environment protection and biodiversity, on rural development and on community development.

\section{Impact of GI on environment and landscape preservation}

By covering more than half of Hasi territory, with almost three-quarters of oaks and a lot of beeches (according to our estimations), forests constitute a significant pastoral resource: vegetable cover under high forests and edible leaves on low forests and scrublands, sinkholes on the plain and fields on the other part of the territory, produce a little part of animal feeding, being the third element that composes the agro-sylvo-pastoral system.

This kind of feeding system not only provides outstanding quality products, but it also plays an essential role for the environment. Grazing presserves open pastoral habitats and limits flammable undergrowth by reducing bush encroachment. Agro-pastoral practices in Hasi region are, though at the origin of a particular and outstanding landscape. Livestock grazing is therefore producing strong positive environmental externalities for such marginal and low productive areas. Goat breeding is the only way to valorize those ligneous resources, converting them into foods products and substantial farm incomes.

There is no doubt that supporting pastoral livestock breeding is a way of maintains an agro-ecosystem which favors biodiversity and landscape ecology. However, it is important to anticipate the effects induced by the introduction of the GI, including the possibility of an increase in the goat population. This increase could be beneficial if it maintains a diverse environment and open areas. On the contrary, it could be detrimental if it results in overgrazing and impairing pasture composition and quality, which is already the case in some areas near to villages. Targeting a balance for suitable pasture carrying capacity implies a careful management of pastoral resources using traditional management practices, at the farm and pastoral unit level, and optimization (both environmental and economic) of the feeding strategy (Garnier et al., 2016).

\section{Impact on rural development}

Geographic indications can have multiple effects on rural areas, their economy, tradition, employment and environment. Their recognition of the special nature of the product gives it a privileged position in the market. Actually promotion of Hasi goat meat GI is sensitizing customers to increase demand for this product. Anyway, this is not enough reflected on the price at farm level because of the lack of a well structured value chain for this product and especially because the gaps in application of traceability are diminishing the effect of GI on the price of the product.

Introduction in the Code of Practice of tradetional farming practices and methods of production helps in keeping alive local tradition and culture, 
and furthermore promotes them in other areas, inreasing the reputation of the product. Self control, internal control of the GI organization as well as control of certifying authority induces strict implementation of traditional farming practices.

On the other side, building and then maintaining the GI requires involvement of several local stakeholders as local government, NGOs, several stakeholders of the value chain, research institutions etc., which brings a positive atmosphere and optimism to local communities. GI building process is accompanied by satellite activities. In Hasi region goat fairs, supported by municipality and other NGOs as well as growing agri-turism are giving the first impact in indirect stimulus to development.

\section{CONCLUSION \\ (LESSONS FROM THE HASI GOAT EXPERIENCE)}

The GI building process has brought shareholders and stakeholders together with a common understanding of challenges, and finds the best fit between private interests, management of the common label, and public good (agro-biodiversity and culture and tradition conservation). It has been complementary to the breed identification process, environmental assessment, production system analyses and support to appropriate pastoral practices.

Geographical Indication building is a complex process that has to combine collective action and knowledge-based product specification of such silvo-pastoral systems.

The development of a quality brand such as Hasi's goat kid meat GI is a complex initiative which requires a commitment of several shareholders and stakeholders, including farmers and farmers organizations, local administration, scientific institutions, NGOs, private businesses, free lance experts, etc. In this process the role of researchers and research institutions is to identify and certify the specifics of the product, those of the territory and local resources, being animal genetics resources or the biodiversity of the pastures. Based on the results of research in different areas related to GI, the code of practice is drafted and a marketing strategy for the product is built, which is also based on economic studies.

Universities and research institutes have the capacity and ability to play an active role in building a collective mark (GI), not only by carrying out applied research to determine product specifications, but also to manage all stages of GI building which are: identification, qualification, remuneration and reproduction (FAO, 2010).

The applied researches in this way are matching to the real needs for the development of collective marks, and become an integral part of the integrated rural development process.

\section{REFERENCES}

[1] Bernard, C., Boutonnet, J-P., Garnier, A., Lerin. F., Medolli, B.: Quality labels: A way to support the development of pastoral resources. Methodological insights based on the monographic analysis of Hasi Region - Northern Albania, Options Méditerranéennes, A, №. 109 (2014).

[2] Dobi, P., Lerin, F., Bardhi, R., Bernard, C., Medolli, B., Garnier, A.: Developing goat kid meat value chain based on geographic indications: an approach for rural development in Albania. VII International Scientific Agriculture Symposium "Agrosym 2016" October 6-9, 2016, Jahorina, Bosnia \& Hercegovina, 2016.

[3] Dobi, P, Hoda, A, Sallaku, E, Kolaneci, V.: Catalogue of Local Small Ruminant Breeds, Tirana, Albania, 2006.

[4] Shabani Egzon: Karakterizimi fenotipik $i$ dhise se Hasit. Master thesis, Agricultural University of Tirana. Albania, 2016.

[5] FAO: Phenotypic Characterization of Animal Genetic Resources, Rome, 2012.

[6] FAO: Linking People, Places and Products. A guide for promoting quality linked to geographical origin and sustainable Geographical Indications. Second edition, 2010.

[7] Garnier, A., Bernard, C. Dobi, P., Launay, F., Lerin, F., Marie, J., Medolli, B., Sirot, B.: Adaptation of an ecological and pastoral diagnosis to the Albanian context: Challenges and lessons learned, CIHEAM-IAMZ, Options Méditerranéennes: Série A. Séminaires Méditerranéens, 2016, ISSN 0253-1542.

[8] Garnier A.: Analyse descriptive d'un terroir du Nord de l'Albanie : le Has. Systèmes d'élevage et ressources pastorales. Ciheam-IamM/Université Montpellier III. Ingénierie et Gestion des Territoires (IGT), Montpellier. 2013, 76 p.

[9] Garnier A.: Pratiques d'élevage et diversité paysagère dans le Has Albanais. Master of Science: Ciheam-IamM, Montpellier (France), 2014, 116 p.

[10] Hoda, A., Biçoku, Y., Dobi, P.: Genetic diversity of Albanian goat breeds revealed by mtDNA sequence variation. Biotechnology \& Biotechnological Equipment, Volume 28, Issue 1 (2014).

[11] Hykaj, G., Hoda, A., Dobi, P., Papa, L., Bakiu, R., Novaku, M.: Population structure and genetic distances between six Albanian local goat breeds using 26 SNP markers, Livestock Research for Rural Development, Volume 25, Number 4, April 2013.

[12] Kipi, A., Mersini, K.: Study on the potentials of the goat meat and cheese in the area of Hasi district (Region of 
Kukes). In the context of quality signs and development of the respective value chains, 2013.

[13] Lloha, I.: Faculty of Biotechnology, Agricultural University of Tirana, Albania (unpublished data/working paper), 2017.
.[14] Medolli B.: Analyse descriptive d'un terroir au Nord de l'Albanie : le Has. Mise en marché et dynamiques des filières des produits animaux. Ciheam-IamM/Université Montpellier III. Ingénierie des projets et des politiques publiques (I3P), Montpellier. 2013, $78 \mathrm{p}$. 